\title{
Interpreting the Right to Bear Arms -- Gun Regulation and Constitutional Law
}

\section{Citation}

Mark Tushnet, Interpreting the Right to Bear Arms -- Gun Regulation and Constitutional Law, 358:14 New Eng. J. Med. 1424 (2008).

\section{Published Version}

http://www.nejm.org/doi/pdf/10.1056/NEJMp0801601

\section{Permanent link}

http://nrs.harvard.edu/urn-3:HUL.InstRepos:10880602

\section{Terms of Use}

This article was downloaded from Harvard University's DASH repository, and is made available under the terms and conditions applicable to Open Access Policy Articles, as set forth at http:// nrs.harvard.edu/urn-3:HUL.InstRepos:dash.current.terms-of-use\#OAP

\section{Share Your Story}

The Harvard community has made this article openly available.

Please share how this access benefits you. Submit a story.

\section{Accessibility}


guns in public, and all but three states generally prohibit local regulation. If people have broadly applicable gun rights under the Constitution, all laws limiting those rights - and criminal convictions based on those laws - will be subject to judicial review. Policymakers will avoid setting other limitations, knowing that court challenges will follow.

Consider Yoshi Hattori's death in light of District of Columbia v. Heller. Rodney Peairs was tried for manslaughter. His lawyer summarized Peairs's defense as follows: "You have the legal right to answer everybody that comes to your door with a gun." A Louisiana jury acquitted him af- ter 3 hours' deliberation. That state's laws now justify homicide under many circumstances, including compelling an intruder to leave a dwelling or place of business, and provide immunity from civil lawsuits in such cases. Thirteen other states have followed suit.

A Supreme Court decision broadening gun rights and overturning the D.C. statutes would be widely viewed as upholding such policies. By promoting our sense of entitlement to gun use against one another, it could weaken the framework of ordered liberty that makes civil society possible.

No potential conflict of interest relevant to this article was reported.
This article (10.1056/NEJMp0800859) was published at www.nejm.org on March 19, 2008.

Dr. Wintemute is a professor of emergency medicine and director of the Violence Prevention Research Program at the University of California, Davis, School of Medicine, Sacramento.

1. Cook PJ, Ludwig JL. Gun violence: the real costs. Oxford, England: Oxford University Press, 2000.

2. Wellford CF, PepperJV, Petrie CV, eds. Firearms and violence: a critical review. Washington, DC: National Academies Press, 2004.

3. Hemenway D. Survey research and selfdefense gun use: an explanation of extreme overestimates. J Crim Law Criminol 1997;87: 1430-45.

4. Loftin C, McDowall D, Wiersema B, Cottey TJ. Effects of restrictive licensing of handguns on homicide and suicide in the District of Columbia. N Engl J Med 1991;325:161520.

5. Parker v. District of Columbia, 478 F.3d 370 (D.C. Cir. 2007).

Copyright (๑) 2008 Massachusetts Medical Society.

\section{Interpreting the Right to Bear Arms Gun Regulation and Constitutional Law}

Mark Tushnet, J.D.

$\mathrm{O}$ n March 18, 2008, the U.S. Supreme Court heard oral arguments in District of Columbia $v$. Heller, a case challenging handgun-control statutes adopted in 1976 in Washington, D.C. The question before the Court is whether the District's prohibition of further registration of handguns, its ban on the carrying of concealed guns, and its mandate that guns kept in homes remain unloaded and either locked or disassembled violate citizens' rights that are guaranteed by the Second Amendment of the Constitution.

What we do about handguns is of course a question of public policy. Because of the Second
Amendment, it is also a question of constitutional law. And the point of constitutional law is to make it difficult for us to adopt some policies that seem to us to be good ones at the moment. The Supreme Court's upcoming decision in District of Columbia $v$. Heller dramatizes the tension between public policy and the Constitution.

The Second Amendment says that "a well regulated Militia, being necessary to the security of a free State, the right of the people to keep and bear Arms, shall not be infringed." Partisans on both sides think that the Amendment's meaning is clear. According to gun-control advo- cates, the opening reference to a militia means that the right protected in the second clause is necessarily limited to keeping and bearing arms in connection with service in an organized militia. According to gun-rights advocates, the second part of the Amendment protects an individual right, no different in kind from the right of free speech protected by the First Amendment.

In fact, interpreting the Second Amendment is a genuinely difficult task, precisely because we have to determine the relation between the first clause, sometimes called the Amendment's preamble, and the second, sometimes called its operative clause. The 
Key Court Rulings about Gun Regulation and the Second Amendment.

United States v. Cruikshank (1876, Supreme Court): Congress does not have the authority to legislate against private interference with the right to bear arms.

Presserv. Illinois (1886, Supreme Court): The Second Amendment protects individuals from federal but not state interference with their right to bear arms.

United States v. Miller (1939, Supreme Court): The Second Amendment does not protect the rights of persons to own firearms that would not be used by a militia.

United States v. Emerson (2002, federal appeals court in Atlanta): The Second Amendment does protect an individual's right to possess firearms, but a law prohibiting persons subject to a domestic-abuse protection order from possessing firearms is constitutional.

Silveira v. Lockyer (2002, federal appeals court in California): The Second Amendment does not protect an individual's right to possess firearms but does protect states' rights to protect themselves.

District of Columbia v. Heller (2007): Federal appeals court rules that D.C. law prohibiting handguns is unconstitutional. Supreme Court grants cert.

preamble could be a condition, limiting the scope of the operative clause, or it could merely be an explanation: "The reason people have an individual right to keep and bear arms is that it makes it easier to provide a militia as the security to a free state." (In the case of District of Columbia $v$. Heller, there's some basically silly discussion of whether the Second Amendment even applies to the District, since it isn't a "state." It's quite clear that the term in the Second Amendment refers to organized governments and not to the narrower group of subnational units we call the states of the United States.)

Gun-control advocates point out that when the term "militia" is used elsewhere in the Constitution, it always refers to the state-organized militia (roughly, though imperfectly, analogous to today's state-organized National Guard). So, they argue, the Second Amendment's preamble also refers to the state-organized militia. To them, the Amendment is part of a package of constitutional provisions expressing the framers' suspicion of a permanent national army. It guarantees that Congress cannot disarm the stateorganized militia. They also point out that in the late 18th century, individuals might have been considered to have a right to "keep" arms, but the phrase "keep and bear arms" was used only in reference to military operations.

Gun-rights advocates have a different view. Their strongest point is that the Bill of Rights is a bill of individual rights. They argue that the Second Amendment's preamble explains why we have an individual right to keep and bear arms. And the "militia" mentioned in the preamble, in this view, is not the state-organized militia but rather what 18th-century thinkers described as the unorganized militia, the whole body of the people who, if armed, would be able to resist efforts by an oppressive government or to provide self-protection when the government failed in its duty to protect against predators and criminals.

This reading does make sense of the preamble's reference to the militia - but at some cost. If the point of the Second Amendment is to allow the body of the people to resist an oppressive government, isn't the Amendment entirely obsolete? Modern governments have tanks and bombs that they could use against the people, and surely, as gun-control advocates say, we can't fairly interpret the Second Amendment as guaranteeing the people a right to own antitank weapons and bazookas. Interpreting the Amendment as protecting weapon ownership only in connection with membership in a stateorganized militia avoids this difficulty.

Such are the arguments regarding the Second Amendment's language as it might have been understood when it was adopted. But constitutional interpretation also takes into account relevant legal tradition; unfortunately, both sides have good arguments on this front as well. On the gun-control side, there's the undoubted fact that state governments have regulated weapon ownership quite extensively since early in the 19th century. The national government didn't get involved in large-scale weapon regulation until the 20th century. But when it did, the courts routinely upheld the regulation because they believed that the Second Amendment protected a right only in connection with membership in a state-organized militia (see box). Such a tradition of extensive regulation of gun ownership that was upheld against constitutional challenge should count for something.

Gun-rights advocates point to another tradition: many state constitutions provide guarantees of what is clearly an individual right to own weapons. And the Supreme 
Court has said - in cases involving the death penalty and assisted suicide - that state-level traditions properly influence the interpretation of provisions in the national Constitution.

The briefs filed in the D.C. case make many additional arguments, but the constitutional question is genuinely difficult. (For what it's worth, my own view is that the gun-rights side has a slightly better argument than its opponents if we focus only on the time when the Amendment was adopted and that the gun-control side has a slightly better argument than its opponents if we use the whole range of constitutional arguments that the courts have said usually matter. But for me, both debates are too close to call.)

So what can we expect from the Supreme Court? Early in the Bush administration, the Department of Justice issued an extensive legal analysis supporting the gun-rights view of the Second Amendment. It has adhered to that position in the D.C. case but with an important twist. Suppose the Second Amendment does protect an individual right. Still, like all rights, that right can be regulated by the government for good reasons - as the Amendment's reference to a "well regulated" militia itself suggests. In the First Amendment setting, we let the government regulate speech only if it has extremely good reasons for the regulation.

The Bush administration argues in the D.C. case that what lawyers call the "standard of review" for

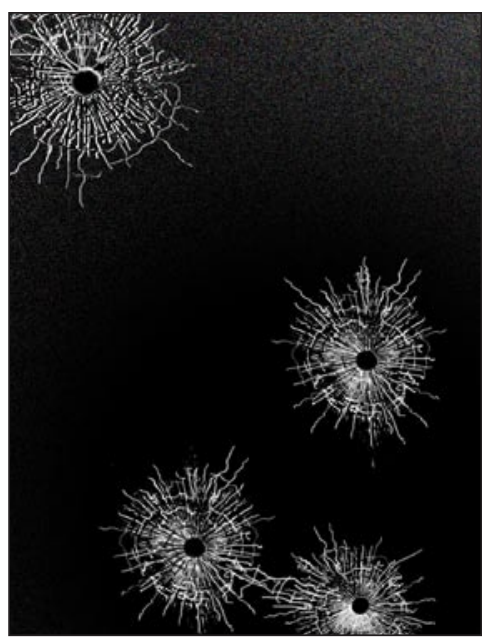

gun regulations is different from that for speech regulations. Lawyers delineate three categories of reasons for regulation: In instances in which really good reasons should be required for restricting a specific right, the regulations are subject to "strict scrutiny" by the courts; in situations in which relatively strong but not overwhelming reasons should be required, the regulations are subject to "intermediate scrutiny"; and when legislators just ought to have some modest reason for thinking that the regulation does some good, the regulation is subject only to "rational basis review." The Bush administration says that the District's handgun ban is subject to intermediate scrutiny and that there is some reason to think it could survive such scrutiny.

The first question the Supreme Court will have to confront in the D.C. case is whether the Second Amendment does indeed protect an individual right. If it finds that it does, the Court will have to decide what standard of review to apply to gun regulations. That, I suspect, is where the real action will be. Nonlawyers watching the Court's decision should focus on the bottom line. If the Court affirms the lower court, it will have held that the Second Amendment protects an individual right and that the District's handgun ban cannot survive the appropriate level of scrutiny. If it vacates the lower court's decision, the Court will be saying that the handgun ban might be constitutional if the lower courts apply the correct standard of review. And if it reverses the lower court, the Court will have rejected the "individual rights" interpretation of the Second Amendment altogether.

No potential conflict of interest relevant to this article was reported.

This article (10.1056/NEJMp0801601) was published at www.nejm.org on March 19, 2008.

Mr. Tushnet is a professor of law at Harvard Law School, Cambridge, MA.

Copyright (c) 2008 Massachusetts Medical Society. 